\title{
Tři starobabylónské matematické tabulky
}

prof. RNDr. Martina Bečvářová, Ph.D.

Ústav aplikované matematiky, Fakulta dopravní,

České vysoké učení technické v Praze

$\triangle$ becvamar@fd.cvut.cz

Orientalia Antiqua Nova XXI

ISBN 978-80-261-1039-2

Západočeská univerzita v PIzni, 2021

https://doi.org/10.24132/ZCU.2021.10392-15-36 


\section{Abstract}

The article analyzes three famous mathematical tablets from the Yale Babylonian Collection (YBC 7290, YBC 7289 , and YBC 7302) that come from the Old Babylonian period (i.e. from some time between 1800 and 1600 BC). They show an interesting approach of ancient Babylonian mathematicians, scribes, or students to elementary planar geometric shapes (trapezoid, square, and circle). They describe the Old Babylonian calculations of areas, the approximation to the square root of 2 as well as the knowledge of the Pythagorean Theorem and the approximation to the value for $\pi$. 


\section{Tabulky s geometrickou tematikou}

Ze starobabylónského období (tj. 19. až 17. století před naším letopočtem) se nám dochovalo množství tabulek s geometrickou tematikou. Obsahuji úlohy, které vycházely zejména z praktických potřeb. Nejvíce podnětů dávalo zemědělství (vyměřování polí a stanovení množství osiva), stavitelství (výpočty objemů zdiva a výkopů, objemů sýpek, výšky staveb, sklonů náspů), obchod (prodej pozemků), válečnictví (budování náspů a hradeb, odhad výšky obranných zdí) a běžný život (rozdělování dědictví a placení daní). Podařilo se však objevit i tabulky, na nichž byly tzv. umělé úlohy, které byly využivány pro výuku písařu a sloužily $\mathrm{k}$ rozvoji jejich matematického myšlení - bylo třeba vypočitat údaje, které se v praxi daly snadno změřit, nebo byly úmyslně zadány nevhodné jednotky nebo vstupní číselné údaje, které komplikovaly výpočty. $\checkmark$ „praktických“ úlohách byly číselné hodnoty většinou zadávány tak, aby výpočty „dobře vycházely“, tj. aby se počtáŕ netrápil komplikovanými aritmetickými operacemi a převodem jednotek.

Na starobabylónských tabulkách se můžeme běžně setkat $s$ výpočtem obsahů elementárních rovinných útvarů (čtverec, obdélník, trojúhelník, lichoběžník, čtyrúnelník, pravidelný pěti-, šesti- a sedmiúhelník, kruh) a s výpočtem objemů více či méně elementárních těles (krychle, kvádr, hranol, klín, komolý klín, nepravidelný klín, válec, jehlan, komolý jehlan, kužel a komolý kužel). Jednalo se o útvary, s nimiž se písař či počtář setkával nebo mohl setkávat $v$ každodenním životě.

V následujícím textu se budeme věnovat třem zajímavým matematickým tabulkám ze starobabylónského období, které neobsahuji žádná slova. Jsou to úlohy z kategorie „dívej se, přemýšlej, uvidíš" neboli úlohy, v nichž je matematika položena před oči bez zbytečného psaní a vysvětlováni. ${ }^{1}$

\footnotetext{
${ }^{1} \mathrm{O}$ matematice ve starověké Mezopotámii viz Bečvář, Bečvářová a Vymazalová 2003, Bruins a Rutten 1961 a Neugebauer a Sachs 1945.
} 


\section{Lichoběžník}

Oblíbeným útvarem starobabylónských matematiků byl lichoběžník. Svědčí o tom velké množství dochovaných tabulek. Nejčastěji se na nich vyskytuje rovnoramenný lichoběžník, který mohl představovat řez zikkuratem nebo výkopem závlahového kanálu vertikální rovinou. Někdy se objevuje pravoúhlý lichoběžník, který mohl reprezentovat řez opěrnou zdí nebo valem.

$\mathrm{Na}$ tabulkách se většinou vyskytuje obrázek, který znázorňuje jeden z výše uvedených typů lichoběžníku, jindy se pouze hovoři o řezu zeminou či zdí nebo se neobratně popisuje pole lichoběžníkového tvaru. Chybí jasná terminologie, není jasné, zda je v úlohách zadána velikost ramene nebo výšky. Dochovaly se tabulky s jednoduchými úlohami, v nichž se počíá obsah lichoběžníku, ale i s obtižnějšími úlohami, kdy je třeba lichoběžník rozdělit na několik částí $s$ předem danými vlastnostmi nebo předem daných tvarů. $K$ řešení takových úloh je někdy nutná znalost podobnosti trojúhelníků, Pythagorovy věty, řešení kvadratických rovnic apod.

Zajímavou tabulkou je tabulka YBC 7290 z období 1800 až 1600 před naším letopočtem, která byla objevena koncem 19. století. Od roku 1909 je součástí celosvětově proslavené Yale Babylonian Collection Yale University New Haven. ${ }^{2}$ Ve dvacátých letech 20. století ji prostudoval historik matematiky

\footnotetext{
${ }^{2}$ Yale Babylonian Collection obsahuje téměr̆ 45000 klínopisných tabulek, je nezávislou částí Yale University Library, která se nacházi v areálu Yale University v New Haven, Connecticut, USA. Sbírka byla založena roku 1909 díky velkolepému daru Johna Pierponta Morgana (1837-1913), předního amerického finančníka, sběratele a filantropa. Dnes je největší světovou sbírkou starověkých klínopisných textů, je centrem výzkumů pro asyriologii a související obory. Více viz https://en.wikipedia.org/wiki/Yale_Babylonian_Collection [20. 5. 2021].
} 
Otto Eduard Neugebauer ${ }^{3}$ a své výsledky publikoval ve čtyřicátých letech. ${ }^{4}$

Jedná se o čtvercovou tabulku popsanou jen z jedné strany, jejiž hrany měři asi $6 \mathrm{~cm}$. Je na ní znázorněn rovnoramenný lichoběžník, uvedena dvě čísla u jeho základen, jedno u jeho ramene a jedno uvnitř. Žádný text na tabulce není. Viz přiložený obrázek. ${ }^{5}$

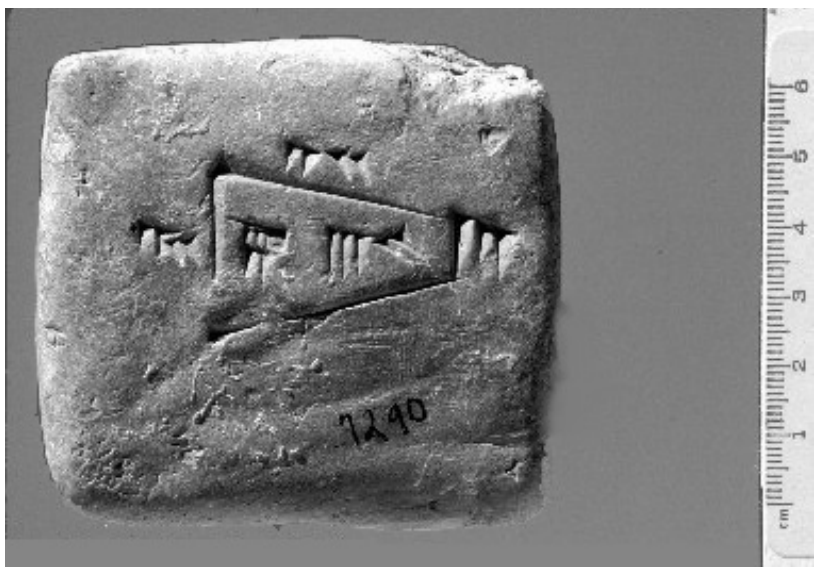

${ }^{3}$ Otto Eduard Neugebauer (1899-1990) byl rakousko-americký matematik a historik vědy, který se proslavil jednak prací pro matematickou komunitu (budování matematického centra v Göttingenu, vedení referativních časopisů) a jednak díky studiím a monografiím z historie vědy, zejména starověké astronomie a matematiky. Byl předním specialistou na studium starobabylónských tabulek. O jeho životě a díle viz např. Veselý 2020.

${ }^{4}$ Zásluhu na první interpretaci této tabulky měli Otto Eduard Neugebauer a Abraham J. Sachs. Abraham J. Sachs (1914-1983) byl americký asyriolog a historik matematiky, který získal vzdělání na Johns Hopkins University. Věnoval se studiu astronomických a matematických klínopisných textů. Prostudoval klínopisné tabulky uložené v USA a Velké Británii. O jeho životě a výsledcích viz např. Toomer 1984.

${ }^{5}$ Obrázek je převzat z Bečvář, Bečvářová a Vymazalová 2003, 321, je také volně dostupný na řadě webových stránek. 
Překreslíme-li obrázek a přepíšeme-li čísla zapsaná klínopisem pomocí našich cifer, ale zachováme-li starobabylónskou šedesátkovou soustavu, obdržíme následující obrázek. ${ }^{6}$

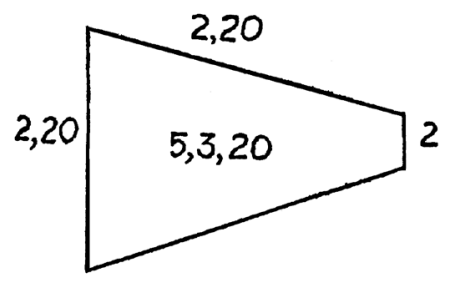

Přepis čísel nečiní žádný problém, nebot̉ zápis na tabulce je nepoškozený a velmi dobře čitelný. U základen lichoběžníku jsou uvedeny hodnoty $(2,20)$ a $(2)$, u ramene $(2,20)$, uvnitř $(5$, $3,20)$. O něco složitější je interpretace řádů čísel, nebot' starobabylónští počtáři sice užívali poziční zápis čísel v šedesátkové soustavě, ale neužívali nulu. Měli speciální znak pro jednotku a speciální znak pro desítku, podle potřeby je aditivně spojovali, například číslo 37 se zapsalo pomocí tři znaků pro desítku a sedmi znaků pro jednotku. Pokud v zápisu byly více než tři stejné znaky, umístovaly se nad sebe, tj. devítka byla zapsána ve třech řádcích, každý obsahoval tři znaky pro jednotku.

Výše uvedený zápis (2) může znamenat (2), (2, 0), (2, 0, 0), (0; 2), $(0 ; 0,2)$ atd. Hodnotu čísla musíme tedy určit podle kontextu nebo vlastního výpočtu. Zdůrazněme, že řády v naší moderní notaci oddělujeme čárkou, celou část čísla od „desetinné“ středníkem, tedy zápis (2) značí v desítkové soustavě 2 , zápis $(2,0)$ je $2 \times 60+0=120$, zápis $(2,0,0)$ udává $2 \times 3600+0 \times 60+0=7200$, zápis $(0 ; 2)$ znamená $2 / 60$ a zápis $(0 ; 0,2)$ představuje $2 / 3600$.

${ }^{6}$ Obrázek je převzat z Bečvář, Bečvářová a Vymazalová 2003, 321, je též volně dostupný na řadě webových stránek. 
Nevíme, zda starobabylónským písařum a počtářum vnímání rádů činilo nějaký větší problém. Je pravděpodobné, že pro začátečníky to mohlo být dosti obtižné, zkušený počtář však správný rád vyrozuměl z kontextu úlohy a prováděných operací. Nemáme dochovanou tabulku, kde by byla chyba způsobená špatným pochopením řádů.

Ze starobabylónských geometrických tabulek víme, že uvnitř útvaru byl obvykle zapisován jeho obsah nebo hodnota související s obsahem (množství osiva, velikost daní apod.). Pokud se zamyslíme nad čísly uvedenými na tabulce YBC 7290, zjistíme, že počtář $\mathrm{k}$ hodnotě obsahu lichoběžníku dospěl tak, jako by užil vzorec

$S=1 / 2 \cdot\left(z_{1}+z_{2}\right) \cdot r$,

kde $z_{1}=(2,20)=2 \times 60+20=140$ („levá“ základna), $z_{2}=(2,0)$ $=2 \times 60=120$ (,pravá“ základna, zde je nutno správně pochopit rád), $r=(2,20)=2 \times 60+20=140$ (rameno). Při této interpretaci uvedených hodnot dostaneme po dosazení do vzorce

$S=1 / 2(140+120) \cdot 140=18200=5 \cdot 3600+3 \cdot 60+20=(5,3,20)$,

což je přesně hodnota uvedená na tabulce.

My však víme, že při výpočtu obsahu lichoběžníku musíme pečlivě rozlišovat rameno a výšku. Výše uvedený starobabylónský postup proto nevede ke správnému výsledku. Náš výpočet se opírá o správný vzorec

$S=1 / 2 \cdot\left(z_{1}+z_{2}\right) \cdot v$,

kde $z_{1}$ a $z_{2}$ jsou základny lichoběžníku a $v$ je výška lichoběžníku. Tu můžeme vypočítat $s$ využitím Pythagorovy věty, která byla 
známa již ve starobabylónském období, byt na žádné tabulce není doložena ani její slovní formulace, ani její matematický důkaz. Délka výšky $v$ se vypočte následovně ( $r$ je rameno)

$v=\sqrt{ }\left[r^{2}-\left(1 / 2 \cdot\left(z_{1}-z_{2}\right)\right)^{2}\right]=\sqrt{ }\left(140^{2}-10^{2}\right)=\sqrt{ } 19500 \approx 139,64$.

Obsah lichoběžníku tedy bude

$S=1 / 2 \cdot(140+120) \cdot \sqrt{ } 19500 \approx 18153,51$.

Porovnáme-li starobabylónskou hodnotu 18200 a naši hodnotu 18153,51 , vidíme, že se príliš neliší. Na této tabulce (na jiných je tomu podobně) ${ }^{7}$ máme „dlouhý a štíhlý“ lichoběžník, tj. lichoběžník, jehož výška se od ramene moc neliší. Starobabylónský počtář se při výpočtu obsahu lichoběžníku dopustil chyby $0,26 \%$. Dnes je těžké rozhodnout, zda si nepřesnost výpočtu uvědomoval, nebo zda nebyla na tabulce vlastně zadána výška a výpočet byl tudiž správný.

Vzhledem ke své velikosti a tvaru (vešla se pohodlně do dlaně), velikosti písma (klínopisné znaky jsou poměrně velké ve srovnání se zápisy na běžných tabulkách) a jednoduchosti obsahu mohla být tabulka YBC $\mathbf{7 2 9 0}$ názornou výukovou pomůckou, která budoucí písaře a počtáre seznamovala s výpočtem obsahu lichoběžníku. Mohla být též školním, cvičným dílem začínajícího písaře - studenta. Jeji přesnou roli dnes již nelze určit. ${ }^{8}$

\footnotetext{
${ }^{7}$ Viz např. starobabylónská tabulka YBC 11126, na níž je lichoběžník se základnami $z_{1}=(45)$ a $z_{2}=(22,30)$, ramenem $r=(3)$ a obsahem $S=(1,41,15)$. Přitom délku (45) je nutno chápat jako $(45,0)$.

${ }^{8}$ O tabulce YBC 7290 viz Bečvář, Bečvářová a Vymazalová 2003, 321-322 a Neugebauer a Sachs 1945, 44.
} 


\section{Čtverec}

$\mathrm{Na}$ dochovaných starobabylónských tabulkách se často pracuje se čtvercovým polem. Z hlediska geometrie se tedy objevuje čtverec, tj. elementární rovinný útvar ohraničený čtveřicí úseček, které jsou stejně dlouhé a po dvou navzájem kolmé. $\mathrm{K}$ jeho zadání stačí jediný údaj (délka strany, resp. délka úhlopříčky, resp. délka obvodu, resp. obsah plochy).

Na dochovaných klínopisných tabulkách jsou počitány obsahy nebo obvody čtverce nebo délka jeho úhlopřičky. Tyto úlohy patři mezi zcela elementární, jedinou jejich komplikací mohou být prevody jednotek nebo násobení víceciferných čísel. Triviálními príklady jsou i takové, kdy je $\mathrm{k}$ řešení nutná znalost Pythagorovy věty (např. výpočet délky úhlopríčky). Tabulek tohoto typu se dochovalo větši množství.

Kromě výše uvedených tabulek máme tabulky, na nichž se řeší obtižnějši úlohy. Patří mezi ně napríklad dělení čtvercového pole na útvary předem daných vlastností nebo tvarů.

Mezi zajímavé tabulky patří tabulka YBC 7289, která pochází z období 1800 až 1600 před naším letopočtem. Byla objevena koncem 19. století, od roku 1909 je součástí Yale Babylonian Collection Yale University New Haven. Ve dvacátých letech 20. století ji prostudoval Otto Eduard Neugebauer, výsledky publikoval ve čtyřicátých letech. Jedná se o nevelkou, nepatrně poškozenou kruhovou tabulku, která je popsána jen z jedné strany, její průměr je asi 7 centimetrů. Je na ní nakreslen čtverec a obě jeho úhlopřičky. U „levé horni“" strany čtverce je uvedeno číslo (30), vidíme tři klínové znaky pro desítku. Přes úhlopřičku je zapsáno číslo $(1,24,51,10)$, vidíme jeden znak pro jednotku, dále dva znaky pro desítku a čtyři znaky pro jednotku, pět znaků pro desítku a jeden znak pro jednotku a nakonec jeden znak pro 
desítku. Pod úhlopřičkou je napsáno číslo $(42,25,35)$, vidíme čtyři znaky pro desítku a dva znaky pro jednotku, dva znaky pro desítku a pět znaků pro jednotku a nakonec tři znaky pro desítku a pět znaků pro jednotku. Zápis čísla 25 je poškozen (viz zápis jednotek). Na levém obrázku vidíme fotografii tabulky, na pravém je tabulka pro lepší názornost překreslena. ${ }^{9}$
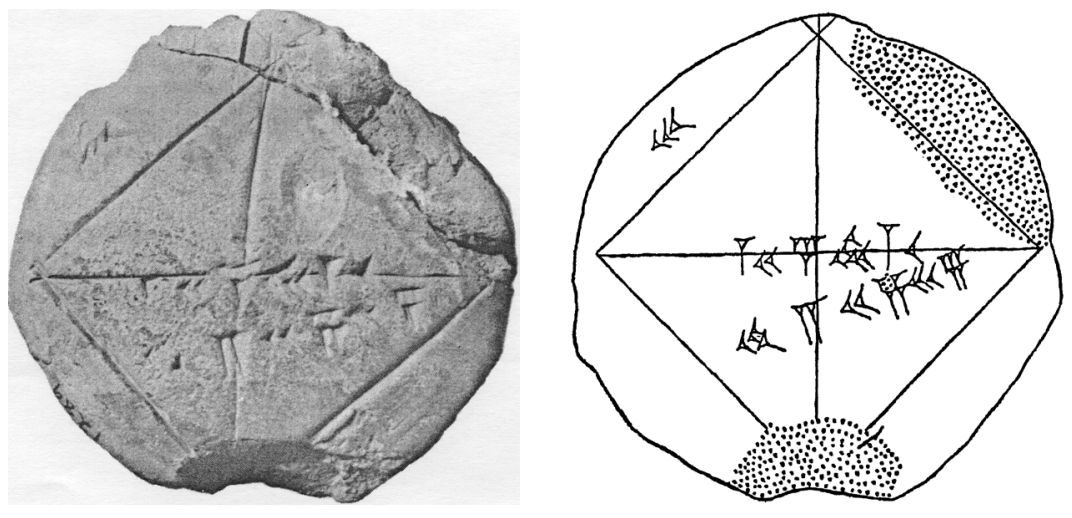

Výklad smyslu zapsaných čisel je následující. První číslo (30) je snadné vysvětlit, nebot je to délka strany čtverce. U zbývajících dvou čísel musíme pečlivě uvážit raády. Číslo na úhlopríčce je nutno číst jako $(1 ; 24,51,10)$ neboli $1+24 / 60+51 / 3600+{ }^{10} / 216000=$ $={ }^{305470} / 216000 \approx 1,414212963 \ldots ., \mathrm{tj}$. jedná se o přibližnou hodnotu $\sqrt{ } 2$. Druhé číslo je nutno číst jako $(42 ; 25,35)$ neboli $42+{ }^{25} / 60+$ $+{ }^{35} / 3600, \mathrm{tj} .30 \times(1 ; 24,51,10)$, což je délka úhlopríčky čtverce se stranou 30 . Viz následující obrázek. ${ }^{10}$

${ }^{9}$ Obrázky jsou převzaty z Bečvář, Bečvářová a Vymazalová 2003, 232, 329 a Neugebauer a Sachs 1945, 42, jsou též volně dostupné na řadě webových stránek.

${ }^{10}$ Obrázek je převzat z Bečvář, Bečvářová a Vymazalová 2003, 329. 


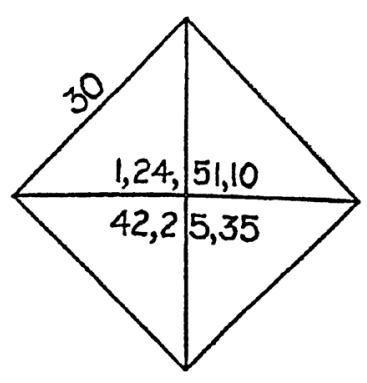

Je zřejmé, že tabulka dokládá znalost Pythagorovy věty asi 1200 let před řeckou matematikou, nebot označíme-li délku strany čtverce $a$ a délku úhlopřičky čtverce $u$, pak platí

$a^{2}+a^{2}=u^{2}$, tj. $u=\sqrt{ } 2 \cdot a$.

Všimněme si starobabylónské hodnoty $\sqrt{ } 2$. Viděli jsme, že číslo $(1 ; 24,51,10)$ je přibližně rovno 1,41212963 . Pokud vypočteme s použitím obyčejné kalkulačky hodnotu čísla $\sqrt{ } 2$, dostaneme přibližnou hodnotu 1,414213562. Přesnost starobabylónského hodnoty je úžasná, výše uvedená číla se shodují na pět desetinných míst. Jako mohlo být takové přesnosti dosaženo? Jaký se za ní skrývá výpočet?

Rekonstrukce starobabylónského postupu vychází z hodnot uvedených na dochovaných tabulkách druhých odmocnin prírozených čísel nebo z údajů použitých na tabulkách obsahujících výpočty délek úhlopřiček čtverců a obdélníkủ. Stručný výpočet je naznačen na tabulce BM 96957 + VAT 6598.11

${ }^{11}$ Část tabulky je uložena v British Museum, Department of Western Asiatic Antiquities (Londýn), část ve Vorderasiatische Abteilung, Tontafeln, Staatliche Museen (Berlín). Analýza tabulky je provedena např. v článku Fowler a Robson 1998, 371-373. V článku jsou diskutovány i jiné způsoby výpočtu druhé odmocniny ze dvou, které ukazují, jak bylo možno elegantně obejít hledání reciproké hodnoty. 
Prvním krokem algoritmu byla tzv. hrubá aproximace, kterou Ize popsat takto: hledejme $\sqrt{ } A$, kde $A$ je přirozené číslo, jehož odmocninu chceme vypočítat. Vyjádříme $A$ ve tvaru $a^{2}+b$, kde a je přirozené číslo takové, že $a^{2}<A$ a $(a+1)^{2}>A$, pririrozené číslo $b$ je pro velká $A$ menši než $a^{2}$. Máme tedy

$\sqrt{ } A=\sqrt{ }\left(a^{2}+b\right)$

a nyní využijeme metodu doplnění na úplný čtverec, tj. zvětšíme výraz pod odmocninou tak, abychom mohli bez problémů odmocnit. Tedy

$\sqrt{ }\left(a^{2}+b\right) \approx \sqrt{ }\left(a^{2}+b+b^{2} / \mathbf{4} a^{2}\right)=a+b / 2 a=1 / 2 \cdot(2 a+b / a)=1 / 2 \cdot(a+$ $+a+b / a)=1 / 2 \cdot\left[a+\left(a^{2}+b\right) / a\right]=1 / 2 \cdot(a+A / a)$.

Takto získaná hodnota odmocniny je větší než skutečná hodnota odmocniny, nebot jsme pridali $b^{2} / 4 a^{2}$. Výše uvedená metoda „hrubé aproximace“ poskytuje vyhovující výsledky při odmocňování velkých přirozených čísel, nebot v těchto případech je $b^{2} / 4 a^{2}$ poměrně malé. Metoda však není postačující pro výpočet odmocnin malých přirozených čísel, což je právě náš případ.

Tohoto problému si starobabylónští počtári museli být dobře vědomi. Z dochovaných matematických tabulek víme, že se s hrubým odhadem nespokojili. Nejprve našli hrubou aproximaci, pak užili metody „průměru“.

Vezmeme-li $a_{1}=1 / 2 \cdot(a+A / a)$ jako první hrubý odhad, potom druhým odhadem bude

$a_{2}=1 / 2 \cdot\left(A / a_{1}+a_{1}\right)$.

Tento vzorec je založen na následujicím výpočtu. Druhý odhad $a_{2}$ předpokládáme ve tvaru 
$a_{2}=a_{1}-x$

a hledáme přirozené číslo $x$ (tj. opravu hrubého odhadu $a_{1}$, který je větší než požadovaná hodnota $\sqrt{ } A$ ). Pro číslo $x$ musí platit

$\left(a_{1}-x\right)^{2} \approx a_{1}^{2}-2 a_{1} x=A$.

Z výše uvedené rovnice snadno vyjádříme $x$

$x=\left(a_{1}^{2}-A\right) / 2 a_{1}$

a tudíž pro $a_{2}$ vyplývá, že

$a_{2}=a_{1}-x=a_{1}-\left(a_{1}^{2}-A\right) / 2 a_{1}=1 / 2 \cdot\left(A / a_{1}+a_{1}\right)$.

Počtář, který hledal druhou odmocninu čísla 2 podle výše uvedeného postupu, vypočítal nejprve hrubý odhad

$\sqrt{ } 2=\sqrt{ }(1+1) \approx 1+1 / 2=3 / 2$.

V šedesátinném zápisu obdržel výsledek (1; 30). Dobře věděl, že výsledek je nepřesný. Proto přistoupil k nalezení druhého odhadu. Vyšel od hodnoty $a_{1}=(1 ; 30)$, po jejím umocnění získal $(1 ; 30)^{2}=(2 ; 15)>(2)$, čímž jen ověřil, že se jedná o hrubou aproximaci. Tento výpočet provedl pomocí tabulek pro násobení, tj.

$\left(1+30 /{ }_{60}\right) \times(1+30 / 60)=1+30 / 60+30 / 60+900 / 3600=2+15 / 60$.

S využitím tabulek reciprokých hodnot ${ }^{12}$ nebo triviálního postupu pro nalezení reciproké hodnoty našel $1 / a_{1}$, a pak vypočetl dvojnásobek nalezené hodnoty, nebot $A=2$, tj. stanovil $2 / a_{1}$.

${ }^{12} \mathrm{O}$ tabulkách reciprokých hodnot viz Bečvár̆, Bečvářová a Vymazalová 2003, 225-229. 
Tedy

$1 /{ }_{(1 ; 30)}=1 / 1,5=2 / 3=40 /{ }_{60}=(0 ; 40)$

a odtud pak

$2 \times(0 ; 40)=2 \times{ }^{40} / 60=80 / 60=60 / 60+20 / 60=(1 ; 20)$.

Nyní mohl pro kontrolu s využitím tabulek pro násobení vypočítat druhou mocninu obdrženého čísla $(1 ; 20)$ a musel dostat číslo menší než 2. Tedy

$(1 ; 20)^{2}=(1+20 / 60) \times(1+20 / 60)=1+20 / 60+20 / 60+400 / 3600=1+40 / 60+$ $+6 / 60+40 / 3600=(1 ; 46,40)<2$

Pak vzal průměr hodnot $a_{1}$ a $2 / a_{1}$ a získal lepší odhad hodnoty druhé odmocniny ze dvou, než poskytl hrubý odhad, nebot'

$a_{2}=1 / 2 \cdot\left(a_{1}+2 / a_{1}\right)=(1 ; 25) \approx 1,4166$.

Jak však vidíme, výše získaná hodnota ještě neodpovídá hodnotě uvedené na tabulce YBC 7289. Shoduje se s naší aproximací odmocniny ze dvou jen na dvě desetinná místa. Starobabylónskou hodnotu $(1 ; 25)$ můžeme nalézt na některých tabulkách $z$ druhého tisíciletí před naším letopočtem; pro technické účely totiž pIně postačovala.

Pokud chceme dosáhnout hodnoty uvedené na tabulce YBC 7289 , bude nutné použít metodu průměru ještě jednou, a to pro startovní hodnotu $a_{2}=(1 ; 25)=85 / 60$. Tento postup se zdá naprosto logický, srozumitelný a snadný.

Pokud však výpočet skutečně zkusíme s využitím jen klasických starobabylónských postupů a pomůcek, zjistíme, že je to 
početně obtižný úkol. Na tabulce reciprokých hodnot priirozených čísel totiž nebyla a nemohla být uvedena reciproká hodnota $k$ číslu $(1 ; 25)$, protože toto číslo není v šedesátkové soustavě číslem regulárním a tudiž $\mathrm{k}$ němu neexistuje přesná reciproká hodnota. Problém je $v$ tom, že čitatel zlomku $85 /{ }_{60}$ nemá tvar $2^{p} \cdot 3^{q} \cdot 5^{r}$, kde $p, q, r$ jsou celá nezáporná čísla, nebot $85=17 \cdot 5$. Číslo 85 tudiž není regulárním číslem a neexistuje $\mathrm{k}$ němu proto reciproká hodnota.

Počtář mohl použit obtižný postup pro přibližný výpočet reciproké hodnoty, potřebovalo by to několik výpočetních kroků. Pravděpodobně by se touto zdlouhavou a náročnou cestou nevydal.

Mohl by též hledat reciprokou hodnotu $\mathrm{k}$ nejbližšímu vhodnému regulárnímu číslu, tj. $k$ číslu $(1 ; 21)=81 / 60$. Tento postup by však nevedl k výraznému zlepšení odhadu druhé odmocniny ze dvou, nebot získaná hodnota by činila $(1 ; 24,56,40) \approx 1,4157$. Shodovala by se s naší aproximací jen na dvě desetinná čísla a byla by jen o málo přesnější než druhá aproximace získaná metodou průměru. Proto by bylo lepši vzít jako nejbližší vhodné regulární číslo „tříciferné“ číslo $(1 ; 25,20)$, tj. ${ }^{5120} / 3600$. Jeho aplikace při použití metody průměru by dala aproximaci druhé odmocniny ze dvou ve tvaru $(1 ; 24,51,15) \approx 1,414236$, jejiž přesnost je však jen na čtyři desetinná místa. Pak by počtář mohl přejít k hledání nejbližšího vhodného regulárního čísla, které by bylo již číslem "čtyřciferným". Tato cesta by byla sice náročná, ale nebyla by nemožná, nebot̉ máme dochovanou tabulku $A O 6456 \mathrm{~s}$ řadou reciprokých čísel z intervalu $(1,0,0,0,0)$ až $(3,0,0,0,0,0) .^{13}$

\footnotetext{
${ }^{13}$ O tabulce AO 6456 viz Bečvář, Bečvářová a Vymazalová 2003, 228-229. Kromě základní tabulky reciprokých čísel menších než 82 existovaly i reciproké tabulky pro čísla druhého řádu, tj. čísla větší než 60, ale menší než 3600. Dochovalo se nám i několik zlomků neúplných tabulek reciprokých čísel třetího řádu.
} 
Počtář mohl také použít tabulku přibližných reciprokých hodnot s aproximací reciproké hodnoty čísla 17. I takové tabulky se nám ze starobabylónského období dochovaly. Pak již stačilo vzít dvanáctinásobek reciproké hodnoty čísla 17 , nebot ${ }^{60} /{ }_{85}=12 / 17=$ $=12 \cdot 1 / 17^{\circ}$

Počtář by tak snadno získal přibližnou reciprokou hodnotu číla $(1 ; 25)$, tj. našel by na tabulce číslo $(0 ; 42,21,10,35)$. Vypočital by jeho dvojnásobek, sečetl jej s číslem $(1 ; 25)$ a ze součtu vypočítal polovinu. Po jistém úsilí by obdržel číslo $(1 ; 24,51,10)$ neboli $1,414212963 \ldots$ To je přesně číslo, které je na tabulce YBC 7289 napsáno na diagonále čtverce. Toto je patrně cesta, kterou se starobabylónský počtáŕ vydal.

Další pěkný postup výpočtu druhé odmocniny ze dvou nabízí Bečvář 2012, 118-119. Je založen na postupném hledání jednotlivých šedesátinných míst a je velmi efektivní. Vychází z dolního hrubého odhadu $a=(1 ; 20)$, který postupně upřesňuje, tj. zvětšuje. Většina teorií vychází z horního odhadu $a=(1 ; 30)$, který postupně upřesňuje, tj. zmenšuje. Podstata výpočtu je stejná. Není možno stanovit, z jakého hrubého odhadu starobabylónští počtáři vycházeli, nebot se nám nedochovala žádná tabulka, na niž by se pracovalo pouze s hrubým odhadem. Jako pravděpodobnější se však jeví využití horniho hrubého odhadu, nebot' máme doloženo užití prvního odhadu ve tvaru $(1 ; 25)$, nikoli ve tvaru $(1 ; 24)$.

Bečvář využivá rovnice $(a+x)^{2}=2$. Zanedbáním $x^{2}$ vypočte $x$ a získá první odhad $a_{1}=(1 ; 24)$. $V$ dalším kroku využije rovnici $\left(a_{1}+x\right)^{2}=2$, zanedbáním $x^{2}$ a zaokrouhlením výsledku (aby obešel dělení číslem 7$)$ vypočte $a_{2}=(1 ; 24,51)$. $V$ závěrečném kroku využije rovnici $\left(a_{2}+x\right)^{2}=2$, zanedbáním $x^{2}$ a zaokrouhlením výsledku (aby obešel komplikované dělení číslem 5091) vypočte $a_{3}=(1 ; 24,51,10)$. Tato jednoduchá metoda by umožnila výpočet 
druhé odmocniny ze dvou s libovolnou přesností, pokud by měl počtář dostatečnou trpělivost a dostatek času. Vystačil by totiž jen s násobením, sčitáním a odčitáním, správným odhadem velikosti výsledku a zaokrouhlováním. Je otázkou, do jaké míry tato metoda odpovídá myšlení starobabylónských počtářu.

Je nutno zdůraznit, že počtář $v$ každém jednotlivém přikladu nejspiše odmocninu ze dvou nepočítal, ale využil standardizovanou tabulku odmocnin malých prirozených čísel nebo tabulku „technických koeficientů“, kterých se nám dochovalo několik, podobně jako tabulek pro násobení a tabulek reciprokých hodnot. Nevíme však, jak byly hodnoty „technických koeficientů“ stanoveny. Je pravděpodobné, že to bylo cestou postupného odhadu s využitím zaokrouhlování.

Poznamenejme, že máme dochovány starobabylónské tabulky, na nichž se pracuje s výše uvedenou vysokou přesností odhadu odmocnin malých přirozených čisel, ale také tabulky, kde se pracuje jen s první (obvykle snadno dostupnou) aproximací. Nemáme však dochované tabulky, kde by se pracovalo jen s hrubým odhadem.

Podle velikosti a tvaru tabulky, velikosti a formy zápisu a jednoduchosti obsahu se usuzuje, že tabulka YBC 7289 byla názornou výukovou pomůckou a seznamovala adepty písařského umění se vztahem délek strany a úhlopřičky čtverce. Mohla však být i cvičnou prací písaře - studenta. Jeji přesnou funkci dnes již nelze určit.14

${ }^{14}$ O tabulce YBC 7289 viz Bečvář, Bečvářová a Vymazalová 2003, 230-232, 328-329 a Neugebauer a Sachs 1945, 42-43. 


\section{Kruh}

Poslední útvar, na který se podíváme, bude kruh, tj. jednoduchý křivočarý útvar, který je zadán jediným údajem (poloměr, resp. průměr, resp. obvod, resp. obsah). Na starobabylónských tabulkách se dochovaly úlohy, $v$ nichž se počitá obsah kruhu nebo objem válcové sýpky či objem věže nebo valu tvaru komolého kužele. Poznamenejme, že starobabylónští počtáři si byli dobře vědomi vztahu mezi obvodem a obsahem kruhu. Počitali však nejčastěji s velmi malou přesností, jejich odhad našeho čísla $\pi$ byl značně nepřesný.

Zajímavá je z tohoto hlediska tabulka YBC 7302, která byla objevena ve druhé polovině třicátých let 20. století v lokalitě Susa (bývalé hlavní město Elamské ríše, dnes Shush v Íránu). Tabulka dnes patři do Yale Babylonian Collection Yale University New Haven. V padesátých letech 20 . století ji prozkoumal, interpretoval a své výsledky publikoval Evert Marie Bruins. ${ }^{15}$ Jedná se o kruhovou tabulku, která je popsána pouze z jedné strany, její průměr je asi 8 centimetrů. Je na ní náčrt kružnice, nad ní je číslo (3), uvnitř číslo (45) a vpravo od ní číslo (9). Na tabulce není žádný text. ${ }^{16}$

\footnotetext{
${ }^{15}$ Evert Marie Bruins (1909-1990) byl holandský aplikovaný matematik, experimentální fyzik a historik matematiky a fyziky. V padesátých letech 20. století dlouhodobě působil na univerzitě v Bagdádu, kde budoval matematický ústav a intenzívně se zajímal o matematické klínopisné texty. V roce 1969 se stal profesorem historie matematiky na univerzitě v Amsterdamu. Zabýval se egyptskou, mezopotamskou a řeckou matematikou. O jeho životě a díle viz např. Knobloch a Hogendijk 1992.

${ }^{16}$ Obrázky jsou převzaty z Bečvář, Bečvářová a Vymazalová 2003, 325, jsou volně dostupné na řadě webových stránek.
} 

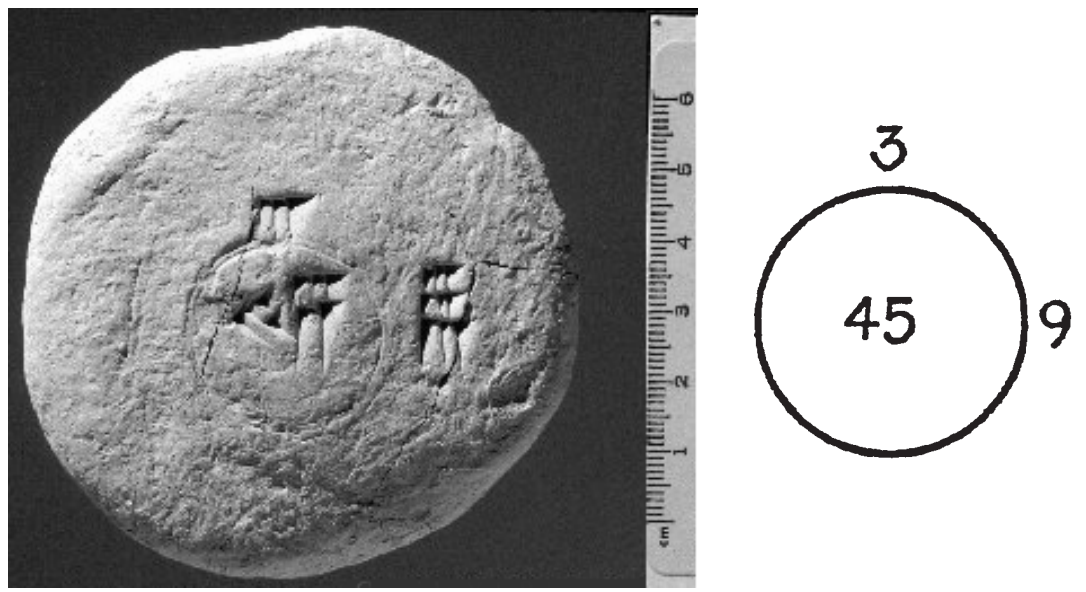

Pravděpodobná interpretace jednotlivých čísel je tato: číslo (3) je obvod kruhu, číslo uvnitř je obsah, je však nutno jej chápat jako $(0 ; 45)$, číslo (9) je druhá mocnina obvodu kruhu a je to číslo pomocné.

Jak dnes postupujeme při výpočtu obsahu kruhu o poloměru $r$ ? Pro výpočet obsahu $S$ kruhu, resp. jeho obvodu o užíváme vzorce

$S=\pi \cdot r^{2}$ a $o=2 \pi \cdot r$.

Ze znalosti obvodu o můžeme vypočitat poloměr $r$, tj. $r=0 / 2 \pi$, dosadíme-li za $r$ do vzorce pro výpočet obsahu $S$ kruhu, získáme vzorec

$S=1 / 4 \pi \cdot 0^{2}$.

Je-li obvod 3, je druhá mocnina obvodu 9, tudíž obsah $S$ kruhu je $S=9 /_{4 \pi} \approx 0,7162$. 
Podíváme-li se znovu na tabulku YBC 7302, vidíme jinou hodnotu obsahu kruhu, a to $(0 ; 45)$, neboli 0,75 . Jak k této hodnotě starobabylónský počtář dospěl? Jaký algoritmus k výpočtu obsahu kruhu použival?

„Standardizovaný“ postup výpočtu obsahu $S$ kruhu ze znalosti délky jeho obvodu o Ize $v$ naší matematické symbolice zapsat vzorcem

$S=1 / 12 \cdot 0^{2}=5 / 60 \cdot 0^{2}$.

Další dochované tabulky tuto interpretaci potvrzují. Ve starobabylónském zápisu by vzorec (kdyby nějaký zapisovali) vypadal takto:

$S=5 \cdot 0^{2}$.

Lze jej snadno vyjádřit těmito slovy: vynásob druhou mocninu obvodu kruhu pěti ( $t j$. pěti šedesátinami). Zdůrazněme, že $v$ exaktní podobě by vzorec zněl

$S=(0 ; 5) \cdot 0^{2}$,

víme však, že se nula na počátku čísla nezapisovala, tj. počtář musel raád čísel pochopit z kontextu.

Na uvedené tabulce YBC 7302 je tedy obsah $S$ stanoven takto: $S=9 \times(0 ; 5)=(0 ; 45)=0,75$. Chyba starobabylónského výpočtu obsahu kruhu je skoro $5 \%$, což je nezvykle vysoká hodnota. Vysvětlení chyby je však jednoduché - starobabylónští počtáři a písaři obyčejně pracovali s hodnotou $\pi=3$, což pro praktické účely (výpočet objemu sýpky, odhad objemu zdiva) plně postačovalo. ${ }^{17}$

${ }^{17}$ Obdobný př́klad je uveden na starobabylónské tabulce YBC 11120, kde je zakreslen kruh s obvodem $(1 ; 30)$ a obsahem $(0 ; 11,15)$. 
Máme však i tabulku ze starobabylónského období, která byla objevena roku 1936 v lokalitě Susa, na níž je použita aproximace $\pi=3 \frac{1}{8}=3,125$, která je přesnější. ${ }^{18}$ Nedosahuje však takové přesnosti odhadu konstanty $\pi$, jakou měli počtáři ve starém Recku.

Poznamenejme, že obvod kružnice byl ve starobabylónských matematických textech patrně počíán pomocí algoritmu, který Ize v naší matematické symbolice vyjádřit vzorcem

$o=\pi \cdot d$,

kde $d$ je průměr kružnice $a \pi$ bylo $v$ naprosté většině případů rovno 3. Bez zajímavosti není, že kruh byl obvykle zadáván délkou svého obvodu, z něhož se v prípadě potřeby počítal průměr nebo poloměr.

Tabulka YBC 7302 vzhledem ke své velikosti a tvaru, velikosti a formě zápisu a jednoduchosti obsahu byla nejspiše výukovou pomůckou a seznamovala budoucí uchazeče o písařské povolání se vztahem obvodu a obsahu kruhu. Vzhledem k úrovni provedení však mohla být i cvičnou prací písaře - studenta. Její přesnou roli již dnes není možno stanovit. ${ }^{19}$

${ }^{18}$ Více viz Bruins a Rutten 1961.

${ }^{19} \mathrm{O}$ tabulce YBC 7302 viz Bečvář, Bečvářová a Vymazalová 2003, 325-326 a Bruins a Rutten 1961. 


\section{Literatura}

Bečvár̆, Jindřich. 2012. „Výpočty odmocnin ve starověku.“ In Archimédés. Několik pohledů do jeho života a dila, vyd. Zdeněk Halas, 111-123. Edice Dějiny matematiky, svazek č. 54. Praha: Matfyzpress.

Bečvář, Jindřich, Martina Bečvářová a Hana Vymazalová. 2003. Matematika ve starověku. Egypt a Mezopotámie. Edice Dějiny matematiky, svazek č. 23. Praha: Prometheus.

Bruins, Evert Marie a Marguerite Rutten. 1961. Textes mathématiques de Suse. Mémoires de la mission archéologique en Iran, svazek č. 34. Paris: Librairie Orientaliste Paul Geuthner.

Fowler, David a Eleonor Robson. 1998. „Square Root Approximations in Old Babylonian Mathematics YBC 7289 in Context." Historia Mathematica 25: 366-378.

Knobloch, Eberhard a Jan Pieter Hogendijk. 1992. „Evert Marie Bruins (1909-1990)." Archives international d'histoire des sciences 42: 317-319.

Neugebauer, Otto a Abraham J. Sachs. 1945. Mathematical Cuneiform Texts. American Oriental Series, svazek č. 29. New Haven (Connecticut): American Oriental Society and the American Schools of Oriental Research (reprint: Wiesbaden: Harrassowitz, 1986).

Toomer, Gerold James. 1984. „Obituary for A.J. Sachs (1914-1983).“ Journal for the History of Astronomy 15: 146-149.

Veselý, Jiří. 2020. „Otto Eduard Neugebauer (1899-1990).“ Pokroky matematiky, fyziky a astronomie 65: 19-35. 